\title{
PENGEMBANGAN MODEL PENERIMAAN MAHASISWA BARU DI PERGURUAN TINGGI KEAGAMAAN ISLAM NEGERI
}

\author{
Mohamad Erihadiana1, Asep Muhyiddin², Tata Sukayat³, Undang Syaripudin", \\ Fildzah Arifah Yoda ${ }^{5}$ \\ 1-5UIN Sunan Gunung Djati Bandung, Indonesia, Jalan A.H Nasution No.105,Cibiru bandung \\ $1^{*}$ Corresponding Author Email: erihadiana@uinsgd.ac.id
}

\begin{abstract}
This research is a focused on the development of a New Student Admission System Model (PMB) at the State Islamic College (PTKIN). By passing the development of the PMB application model at PTKIN, it can be obtained input from students who are able to achieve high academic achievements. To develop this model, it is necessary to first describe the policy for the new student admission of the State Islamic Religious College (PTKIN) in Indonesia and to conduct a study on the admission of new students at two PTKIN, namely UIN Sunan Gunung Djati Bandung and UIN Sultan Syarif Kasim Riau. In addition to conducting studies on the admission system of new students at the leading universities in Southeast Asia, namely Asia e-University Malaysia. Based on the results of research and theoretical analysis, a web-based or information technology-based application design for new student admissions was made. A qualitative type approach, research and development (R \& D) is the approach used in this research. In order to produce results in the form of PMB in PTKIN. The model is an online or web-based model developed for the benefit of academic quality. The PMB acceptance application uses an object-aimed approach in the Unified Modeling Language (UML) method to get the results of this study. The design contains a system using a model and can be expressed as part of a divided function using a Use Case diagram. Then the system used by actors with activity rules is an Activity diagram analysis. As for those who use the class planning stage from the class analysis stage, namely the Activity Class Diagram. Then sequence diagrams, network architecture, and system architecture.
\end{abstract}

Keywords: Model Development, State Islamic Religious College, Policy Studies

\begin{abstract}
ABSTRAK
Penelitian ini membahas Pengembangan Model Sistem Penerimaan Mahasiswa Baru (PMB) pada lembaga Perguruan Tinggi Keagamaan Islam Negeri (PTKIN). Dengan melewati pengembangan model aplikasi PMB di PTKIN ini dapat diperoleh input mahasiswa yang mampu berprestasi akademik tinggi. Untuk mengembangkan model tersebut, maka dideskrispsikan terlebih dahulu tentang kebijakan Penerimaan Mahasiswa Baru Perguruan Tinggi Keagamaan Islam Negeri (PTKIN) di Indonesia dan melakukan studi tentang penerimaan mahasiswa baru di dua PTKIN yaitu UIN Sunan Gunung Djati Bandung dan UIN Sultan Syarif Kasim Riau. Di samping melakukan studi sistem penerimaan mahasiswa baru di perguruan tinggi terkemuka di Asia Tenggara yaitu Asia e-University Malaysia. Berdasarkan hasil riset dan analisis teori, maka dibuatlah rancangan aplikasi penerimaan mahasiswa baru Perguruan Tinggi Agama Islam Negeri berbasis web atau teknologi informasi. Pendekatan jenis kualitatif, riset dan pengembangan (R \& D) merupakan pendekatan yang digunakan dalam penelitian ini. Guna untuk menghasilkan hasil yang berbentuk PMB di PTKIN. Model tersebut adalah model berbasis online atau web yang dikembangkan untuk kepentingan mutu akademik. Aplikasi penerimaan PMB menggunakan pendekatan yang bertujuan objek pada metode Unified Modeling Language (UML) untuk mendapatkan hasil pada penelitian ini. Perancangannya memuat system dengan menggunakan model dan dapat dinyatakan bagian dari fungsi yang tersedia dengan menggunakan Use Case diagram. Kemudian system yang digunakan actor dengan aturan aktifitas merupakan analisis Activity diagram. Adapun yang menggunakan tahap perencanaan kelas dari tahap analisis kelas yaitu Activity class diagram. Kemudian sequence diagram, arsitekstur jaringan, dan arsitekstur sistem.
\end{abstract}

Kata Kunci: Pengembangan Model, Perguruan Tinggi Keagamaan Islam Negeri, Studi Kebijakan

* Copyright (c) 2021 Mohamad Erihadiana et.al

This work is licensed under a Creative Commons Attribution-ShareAlike 4.0 International License. 


\section{PENDAHULUAN}

Perguruan Tinggi Keagamaan Islam Negeri (PTKIN) yang tersebar di seluruh Indonesia sudah sejak lama berdiri dan berkontribusi kepada kemajuan pendidikan nasional. Keberadaan PTKIN di Indonesia tidak bisa dipandang sebelah mata karena eksistensinya terbukti dibutuhkan oleh masyarakat serta tumbuh menjadi pusat kajian Islam, pengetahuan, dan teknologi (Muzhiat \& Kartanegara, 2020; Suharto, 2021). Kenyataan tersebut tentu saja harus dipertahankan bahkan ditingkatkan. Oleh karena itu, keberadaan PTKIN harus didasari oleh tradisi ilmiah yang kuat. Budaya keilmuan semacam itu dapat berkembang bilamana syarat pendukungnya dapat terpenuhi, seperti memperluasnya akses, meningkatkan kelas serta koneksi, dan meningkatkan pengelolaan perguruan tinggi (Panitia Pelaksana Seleksi Penerimaan Mahasiswa Baru PTKIN, 2015).

Di dalam syarat-syarat tersebut, terdapat beberapa PTKIN seperti Institut Agama Islam Negeri (IAIN), Sekolah Tinggi Agama Islam Negeri (STAIN), dan Universitas Islam Negeri (UIN) itu merupakan suatu bentuk sistem yang mencakup pada sub-sistem, seperti: input, process, dan output. Menentukan kualitas dari output PTKIN dilihat dari kualitas input nya. Oleh sebab itu, calon mahasiswa yang diinput oleh PTKIN diharuskan mengikuti seleksi dengan cara mengikuti sistem penyeleksian yang legal dan terjamin. Dengan syarat tetap mengamati keperluan apa saja dalam mengembangkan PTKIN di masa yang akan datang (Panitia Pelaksana Seleksi Penerimaan Mahasiswa Baru PTKIN, 2015).

Pada tahap selanjutnya, akan dibutuhkan berbagai model pengembangan sistem penerimaan mahasiswa baru di PTKIN (Jannah et al., 2017; Tambunan et al., 2020). Sebab itu dipandang penting mengetahui sistem penerimaan mahasiswa baru di berbagi perguruan tinggi ternama di Asia Tenggara, karena bagaimanapun sistem penerimaan baru adalah bagian dari keseluruhan sistem pembelajaran sehingga berhasil menjadi universitas yang memiliki mutu lulusan yang baik. Penelitian ini berupaya melakukan studi perbandingan sistem penerimaan mahasiswa baru di Asia Tenggara dalam rangka pengembangan model penerimaan mahasiswa baru di PTKIN (Panitia Pelaksana, 2017).

Berdasarkan adanya kebutuhan model sistem penerimaan mahasiswa baru di PTKIN , maka Fokus dari penelitian ini adalah pengembangan model sistem penerimaan mahasiswa baru di perguruan tinggi keagamaan Islam negeri berbasis web atau online (Islami, 2018). Sistem penerimaan mahasiswa baru di PTKIN pada dasarnya adalah penerapan suatu kebijakan dari Kementrian Agama selaku regulator PTKIN. Tidak hanya bersangkutan dengan mekanisme pendefinisian dari beberapa keputusan politik yang prosesnya melalui prosedur birokrasi. Penerapan kebijakan ini juga melibatkan suatu masalah, ketetapan, dan pemerolehan suatu kebijakan (Alviana \& Kurniawan, 2019).

Oleh karena itu, mulai dari sebuah proses kebijakan, semua pelaksanaan akan menjadi suatu aspek yang penting. Udoji berpendapat bahwa "the exsution of policies is as important if not more important than policy-making. Polices will remain dreams or blue prints file jackets unless they are implemented" (melaksanakan suatu kebijakan sama halnya dengan kepentingan yang jauh lebih penting dari peraturan kebijakan. Kebijakan hanya berbentuk impian atau harapan indah jika tidak diterapkan (Moleong \& Surjaman, 1991).

Seharusnya tolak pikir diperingati soal implementasi yang sebagian besarnya adalah program pemerintah yang pasti bisa mengaitkan beberapa pembuat kebijakan untuk menghasut perbuatan birokrasi (street level bureaucrats) dengan hal lain dapat melayani masyarakat dengan mengatur Tindakan dari satu atau lebih sasaran. Dapat dilihat dari 3 pendapat dalam mengimplementasikan program yang melibatkan instansi dari berbagai tingkatan struktur organisasi, yaitu: 1. Penggegas kebijakan (the center); 2. Para pejabat pelaksana (the periphery); 3. Incaran suatu kelompok (target group) (Madjid, 2018). 
Kemajuan teknologi yang cepat pada masa sekarang ditandai dengan semakin mudahnya manusia mendapatkan akses informasi dan melakukan aktivitas daring melalui internet (Akbar \& Noviani, 2019; Switri, 2019; Wahyudi \& Sukmasari, 2018). Hampir semua orang pada saat ini dapat menggunakan teknologi internet atau teknologi berbasis web. Melalui teknologi berbasis web inilah dibuat sistem pendaftaran mahasiswa baru yang sanggup menggarap sebuah data menjadi efektif dan efisien. Persoalan utamanya adalah bagaimana system computer bisa mendukung suatu efektivitas pada pendaftaran mahasiswa yang dapat diaplikasikan. Selain bertujuan untuk mempermudah dalam melakukan pendaftaran mahasiswa baru juga mendapatkan hasil lulusan yang diharapkan mampu memiliki prestasi belajar yang tinggi di perguruan tinggi. Namun beberapa penelitian yang ada masih memiliki kajian yang sejenis/satu objek (Muslihudin \& Larasati, 2017; Suryadi, 2018; Tyas, 2019) belum melakukan pembahasan mendalam dengan cara membanding beberapa sistem aplikasi penerimaan mahasiswa baru. Untuk itu peneliti memiliki tujuan membahas Pengembangan Model Sistem Penerimaan Mahasiswa Baru (PMB) pada lembaga Perguruan Tinggi Keagamaan Islam Negeri (PTKIN) dengan membandingkan dengan sistem aplikasi universitas lainnya .

Beberapa hal yang berkaitan dengan sistem pendaftaran mahasiswa Berbasis online atau webdi antaranya: (1) Konsep Dasar Sistem; (2) Karakteristik Sistem; (3) konsep dasar informasi; (4) Manfaat informasi sistem; (5) keamanan informasi; (6) nilai informasi; (7) konsep dasar sistem informasi; (8) komponen sistem informasi; (9) pengelompokan komponen sitem informasi.

\section{METODE PENELITIAN}

Pada penelitian ini penulis menggunakan pendekatan mix methods atau dengan menggunakan dua pendekatan, yaitu pendekatan kualitatif dengan pendekatan berupa penelitian serta pengembangan (research and development atau R and D). Pendekatan kualitatif dalam penelitian ini, menggambarkan fenomena-fenomena yang ada dalam situasi yang wajar dalam pengimplementasian kebijakansistem penerimaan mahasiswa baru di PTKIN dan universitas di Asia Tenggara (Malaysia). Data yang diperoleh dimaksudkan untuk mengungkapkan, menganalisis, dan mengevaluasi implementasi kebijakan sistem penerimaan mahasiswa baru di PTKIN dan universitas di Asia Tenggara yaitu Malaysia. Pada penelitian ini, penulis menggunakan metode analisis kebijakan (Aziz et al., 2020). Analisis Kebijakan sebagai sebuah metode dalam penelitian kualitatif adalah menganalisis dengan metode deskriptif yang meliputi analisis konten (content analycic) dan analisis sejarah (historical analysis) (Anggito \& Setiawan, 2018).

Analisis deskriptif yang mencakup analisis isi (content analysis) dan analisis sejarah (historical analysis). Untuk menemukan suatu kedudukan, kemauan atau tekad, pengertian, dan keterlibatan antar dokumen, resiko, dan efek-efek positif maupun negative dari suatu kebijakan, yaitu dengan menggunakan analisis kebijakan. Analisis kebijakan tidak berarti intervensi isi kebijakan, tetapi menganalisis relevansi, konsistensi, dan makna strategis sistem penerimaan mahasiswa baru di PTKIN dan universitas di Asia Tenggara. Penelitian analisis kebijakan digunakan agar mendapatkan peranan, kekuasaan, nilai, dan implikasi antar dokumen, konsekuensi, dan dampak positif ataupun negative dari kebijakan itu sendiri(Sukmadinata, 2011).

Pendekatan dengan cara mengembangkan dan mempraktekan salah satu produk yaitu pendekatan penelitian dan pengembangan (research and development atau R \& D)(Sukmadinata, 2011). Pada pendekatan ini memiliki 3 tahapan, yaitu: (1) studi pendahuluan; (2) pengembangan model; (3) uji model. Studi pendahuluan dilakukan dengan mengkaji teori dan mengamati model atau kegiatan yang ada. Sedangkan pengembangan model adalah melakukan pengembangan produk atau model baru. Dengan 
Khazanah Pendidikan Islam, Vol. 3 No. 2: 82 - 91

Pengembangan Model Penerimaan Mahasiswa Baru di Perguruan Tinggi Keagamaan Islam Negeri Mohamad Erihadiana et.al

contoh yang tidak banyak dan terlalu luas, kegiatan ini telah melalui beberapa tahapan uji coba. Adapun uji model dilakukan dengan mengadakaneksperimen (Syahrum, 2012).

Pengumpulan data dengan melalui penelitian ini meliputi beberapa dokumen resmi seperti peraturan dari pemerintah, Undang-Undang, dan keputusan dari Menteri terkait dengan kebijakan sistem penerimaan mahasiswa baru; buku-buku pedoman penerimaan mahasiswa baru, dan catatan-catatan fisik serta laporan-laporan lainnya yang digunakan yang relevan dengan penerimaan mahasiswa baru. Hasil penelitian ini adalah Model aplikasi PMB di PTKIN.

\section{HASIL DAN PEMBAHASAN}

\section{Hasil}

\section{Deskripsi Sistem Penerimaan Mahasiswa Baru}

Lokasi penelitian yang menjadi objek penelitian adalah: (1) Universitas Islam Negeri Sunan Gunung Djati Bandung; (2) Universitas Islam Negeri Sulatan Syarif Kasim Riau; dan (3) Asia e-University Malaysia. Sesuai dengan tujuan penelitian ini, ketiga perguruan tinggi tersebut dijadikan lokasi penelitian untuk memperoleh informasi mengenai sistem atau model penerimaaan mahasiswa baru sehingga diperoleh gambaran yang jelas sebagai bahan perbandingan dan analisis mengenai sistem yang digunakan dalam rekruitmen mahasiswa untuk memperoleh input yang baik dan menunjang kepada proses serta prestasi belajar atau output lulusan.

\section{UIN Sunan Gunung Djati Bandung}

UIN Sunan Gunung Djati Bandung menerima calon mahasiswa melalui melalui 4 jalur nasional yaitu: (1) SPAN-PTKIN (Seleksi Prestasi Akademik Nasional Perguruan Tinggi Keagamaan Islam Negeri); (2) SNMPTN (Seleksi Nasional Masuk Perguruan Tinggi Negeri); (3) SBMPTN (Seleksi Bersama Masuk Perguruan Tinggi Negeri); dan (4) UM-PTKIN (Ujian Masuk Perguruan Tinggi Keagamaan Islam Negeri).

Selain itupenerimaan mahasiswa baru juga dilaksanakan melalui jalur mandiri melalui: (1) Ujian mandiri dengan sistem CBT (Computer Based Testing); (2) Jalur Khusus Tahfidz al-Qur'an (minimal 5 Juz); (3) Jalur Prestasi Seni dan Olahraga.

Hal tersebut mengacu kepada Pedoman Akademik UIN Sunan Gunung Djati Bandung bahwa Penerimaan Mahasiswa Baru Program Sarjana dapat dilakukan melalui jalur khusus yaitu: (1) Jalur Khusus Tahfidz al-Qur'an (minimal 5 Juz); dan (2) Jalur Prestasi Seni dan Olahraga minimal tingkat regional (PTIPD UIN SGD, 2018).

\section{UIN Sultan Syarif Kasim Riau}

Sistem Penerimaan Mahasiswa baru di UIN Sultan Syarif kasim Riau untuk jalur nasional tidak berbeda dengan UIN Sunan Gunung Djati Bandung Sedangkan penerimaan mahasiswa baru melalui jalur mandiri di UIN Sultan Syarif Kasim Riau dilakukan melalui jalur mandiri undangan dan jalur CBT (Computer Based Testing).

Penyeleksian yang dilakukan melalui jalur prestasi akademik tanpa harus mengikuti ujian tulis yaitu disebut dengan PMB (Penerimaan Mahasiswa Baru) melalui undangan dari jalur mandiri. SMA/SMK/MA/MAK/Pondok Pesantren, baik itu lembaga negeri ataupun swasta adalah system dan prosedur dalam penyeleksian dengan jalur mandiri undangan mandiri ini. Dengan cara dikirimkan undangan resmi dari Rektor UIN Sultan Syarif Kasim Riau. Begitupun jika ada sekolah yang tidak 
Khazanah Pendidikan Islam, Vol. 3 No. 2: 82 - 91

Pengembangan Model Penerimaan Mahasiswa Baru di Perguruan Tinggi Keagamaan Islam Negeri

Mohamad Erihadiana et.al

dikirimkan surat undangan tersebut, maka pihak sekolah bisa membuat ajuan permintaan secara tulis untuk Rektor dengan membawa dokumen akreditasi sekolah (Panitia Penerimaan Mahasiswa Baru UIN SUSKA Riau, 2018).

Ujian CBT merupakan jalur penyeleksian dalam penerimaan calon mahasiswa di berbagai universitas, salah satunya ialah UIN Suska Riau. Adapun pendaftarannya bisa melalui situs online http://pmb.uin-suska.ac.id.

\section{Asia e-University Malaysia}

Asia e-University (AeU) adalah universitas yang menggunakan pembelajaran dengan sistem dualmode (tatap muka dan pembelajaran jarak jauh online). Asia e-University menyatakan diirinya sebagai universitas atau lembaga pendidikan global untuk menawarkan kualitas, terjangkau dan program perkuliahan melalui e-learning dan lintas negara dan lintas-budaya.

A e-Universiti adalah fasilatator utama dari Asia Credit Transfer System (ACTS) atau program trasnfer akademik antara lembaga-lembaga pendidikan di Asia. The ACTS adalah bagian dari upaya CSR Asia e-University dalam mempersempit kesenjangan digital antara masyarakat di Asia. Pembelajaran di Asia e-University fokus kepada kesediaan mahasiswa untuk belajar. AeU menyediakan pendidikan bagi para profesional mencari fleksibilitas, inovasi dan kreativitas bekerja untuk memenuhi kebutuhan pendidikan mereka.

Sistem Penerimaan mahsiswa baru tidak dibatasi waktu, tetapi tersedia secara daring sesuai dengan kesediaan dan jumlah mahasiswa yang akan mengikuti perkuliahan.

\section{Perbandingan Aplikasi Penerimaan Mahasiswa}

Mengacu kepada Pedoman Akademik UIN Sunan Gunung Djati Bandung bahwa Penerimaan Mahasiswa Baru Program Sarjana dapat dilakukan melalui jalur mandiri CBT (Computer Based Test) dan jalur khusus yang meliputi: (1) Jalur Khusus Tahfidz al-Qur'an (minimal 5 Juz); dan (2) Jalur Prestasi Seni dan Olahraga minimal tingkat regional. Tatacara pendaftaran dan pelaksanaan ujian/seleksi jalur mandiri Computer Based Test (CBT) dan jalur khusus mengikuti ketentuan seleksi mandiri melalui pendaftaran secara online dengan mengunggah (upload) bukti prestasi berupa sertifkat atau keterangan lainnya dan mengikuti seleksi khusus tahfiz al-Quran atau prestasi olahraga dan seni.

Sedangkan di UIN Sultan Syarif Kasim Riau Sebelum melakukan pendaftaran sebagai mahasiswa baru, akan terdapat tampilan awal website Penerimaan Mahasiswa Baru (PMB). Pada tampilan awal website, calon mahasiswa dapat melihat alur dari Penerimaan Mahasiswa Baru (PMB) untuk jalur undangan mandiri.

Pada Gambar 1 dan 2 dapat dilihat tampilan awal Penerimaan Mahasiswa Baru (PMB) untuk Jalur Undangan Mandiri : 
Khazanah Pendidikan Islam, Vol. 3 No. 2: 82 - 91

Pengembangan Model Penerimaan Mahasiswa Baru di Perguruan Tinggi Keagamaan Islam Negeri Mohamad Erihadiana et.al

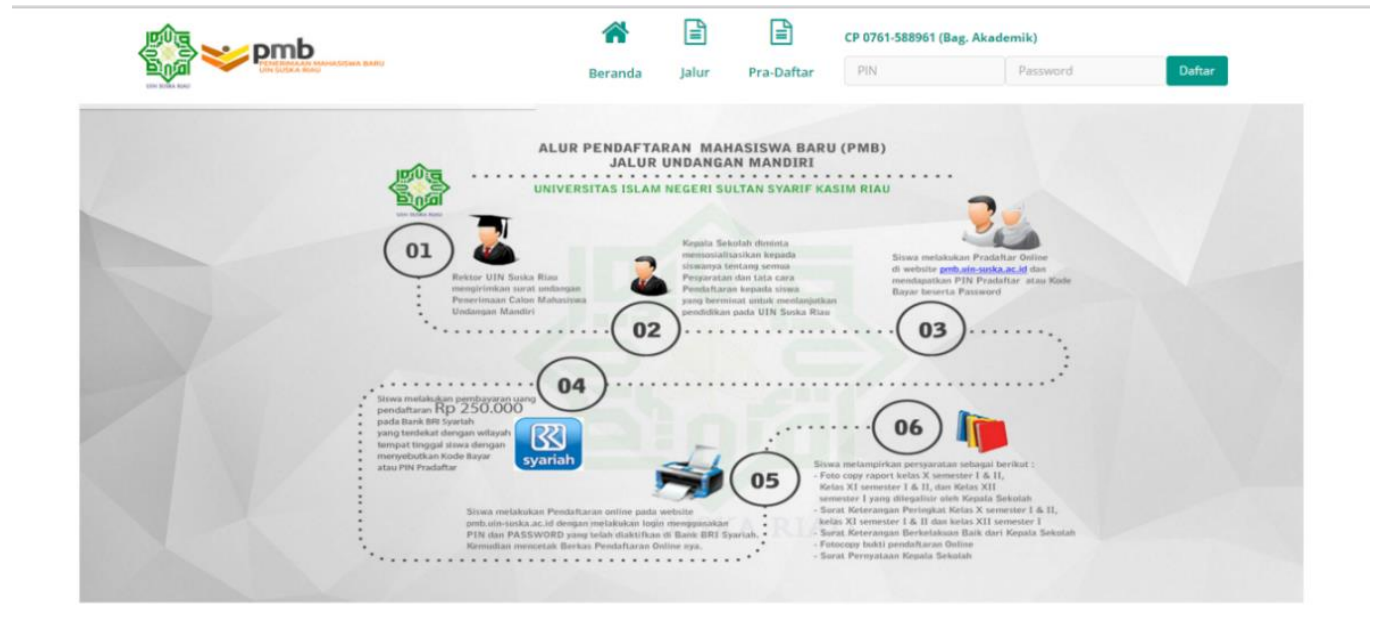

Gambar 1. Tampilan Awal Web PMB UIN Suska

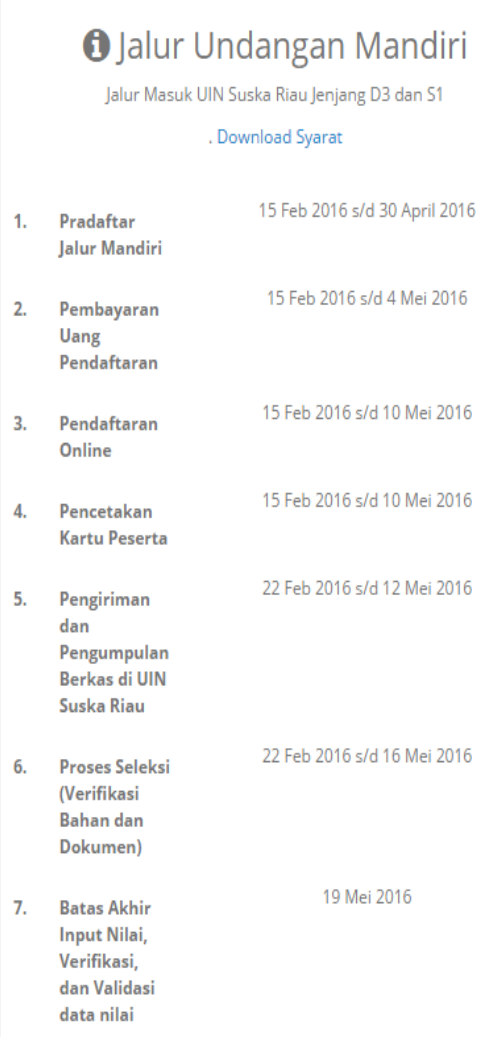
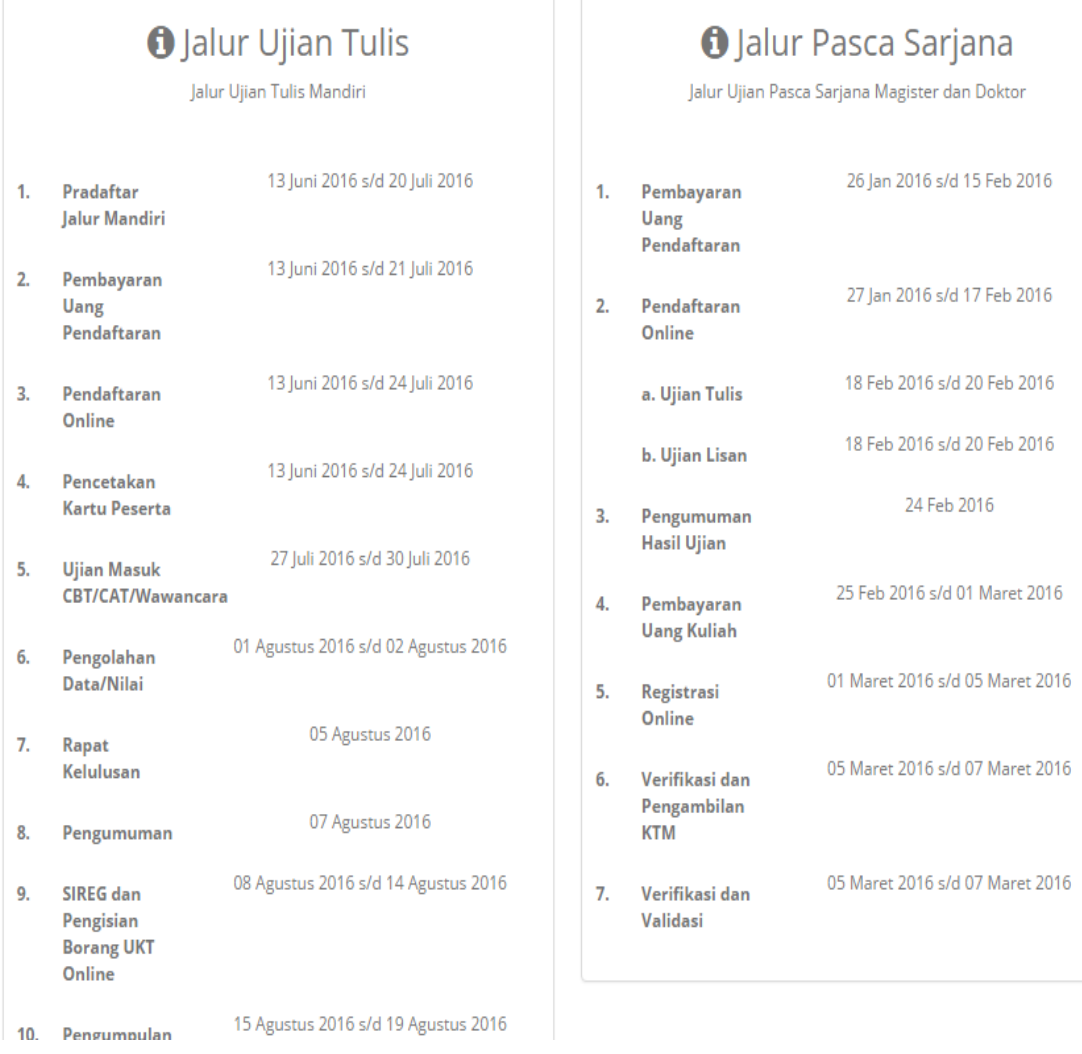

Gambar 2. Tampilan Awal Web PMB UIN Suska

Setelah melalui beberapa tahap pengisian online baru kemudian calon mahasiswa melakukan verifikasi dan dilakukan pencetakan maka tampilan cetak data inputan ada pada gambar 3 : 
Khazanah Pendidikan Islam, Vol. 3 No. 2: 82 - 91

Pengembangan Model Penerimaan Mahasiswa Baru di Perguruan Tinggi Keagamaan Islam Negeri Mohamad Erihadiana et.al

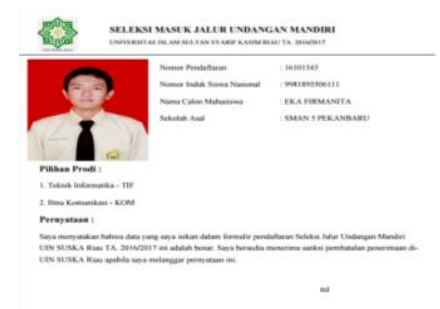

Gambar 3. Tampilan Cetak Data Inputan

Sistem aplikasi penerimaan mahasiswa baru Asia e-Univesity Malaysia secara sederhana dapat digambarkan dalam flowchart Standar Operasional Prosedur (SOP) lihat gambar 4.

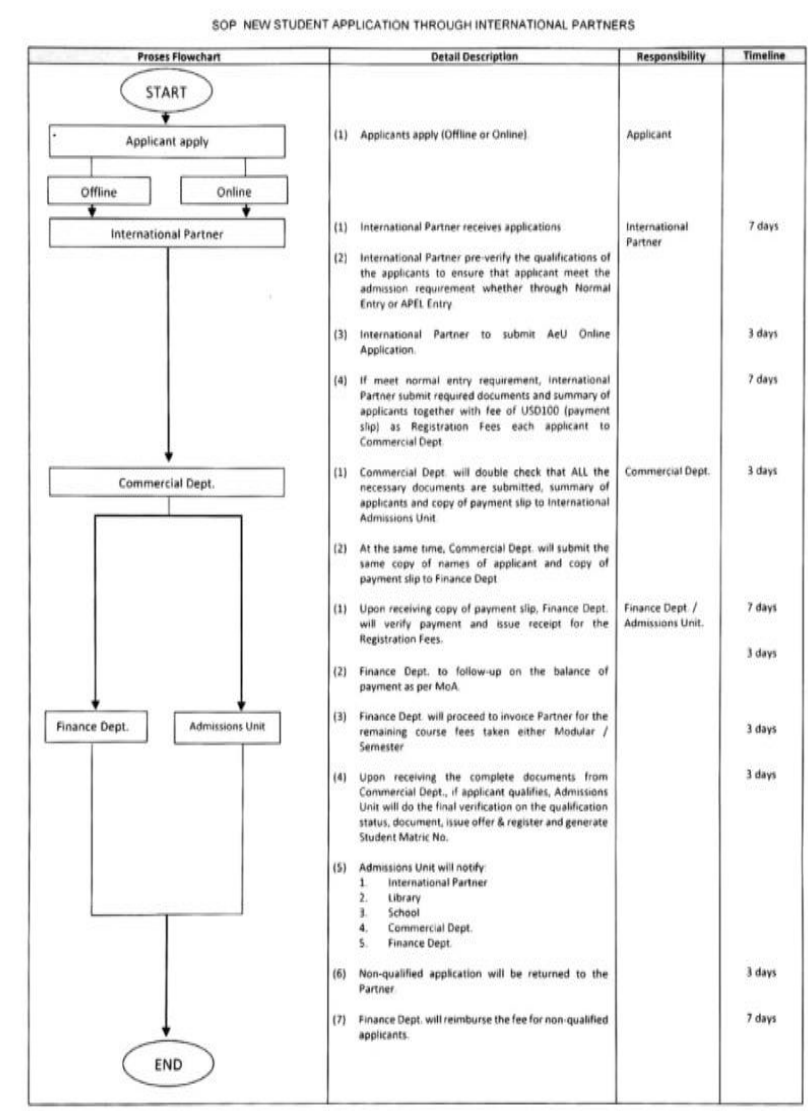

Registry, Admissions and Records

Scanned by CamScanner

Gambar 4. Standar Operasional Prosedur (SOP Asia e-Univesity Malaysia 


\section{Diskusi}

Berdasarkan hasil analisis teori dan perbandingan sistem penerimaan mahasiswa baru di UIN Sunan Gunung Djati Bandung, UIN Sultan Syarif Kasim Riau, dan Asia e-University Malaysia, maka dibuat Aplikasi penerimaan Mahasiswa dengan menggunakan Unified Modeling Language. UML dapat dijadikan standar di kemudian hari dengan industry dalam mengembangkan system atau perangkat lunak dengan menggunakan salah satu alat bantu yaitu Unified Modeling Language yang biasa digunakan oleh banyak pihak besar seperti perusahaan Microsoft, IBM dan lain-lainnya.

Tahap seperti ini pada proses pembuatan sistemnya yang menggunakan metode dari Prototyping Model (Mubarok et al., 2015) dapat dilakukan dengan tersusun dan terdapat beberapa tahap yang mesti dilewati oleh pembuatnya. System yang akan dievaluasi dan diulang kembali dari awal prosesnya ialah system yang terdapat kekurangan di dalamnya. Pada system prototyping Model, bisa dimaknai dengan penciptaan system software dengan menggunakan metode siklus. Dan pada system ini terdapat 5 tahapan, Lihat gambar 5:

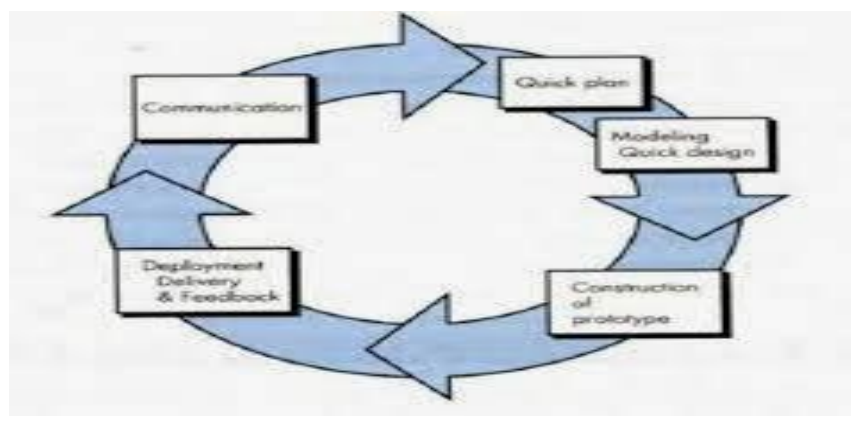

Gambar 5. Metode Prototipe

Hasil akhir tampilan pada web sebagaimana dalam tampilan antarmuka pada gambar 6 dan gambar 7 .

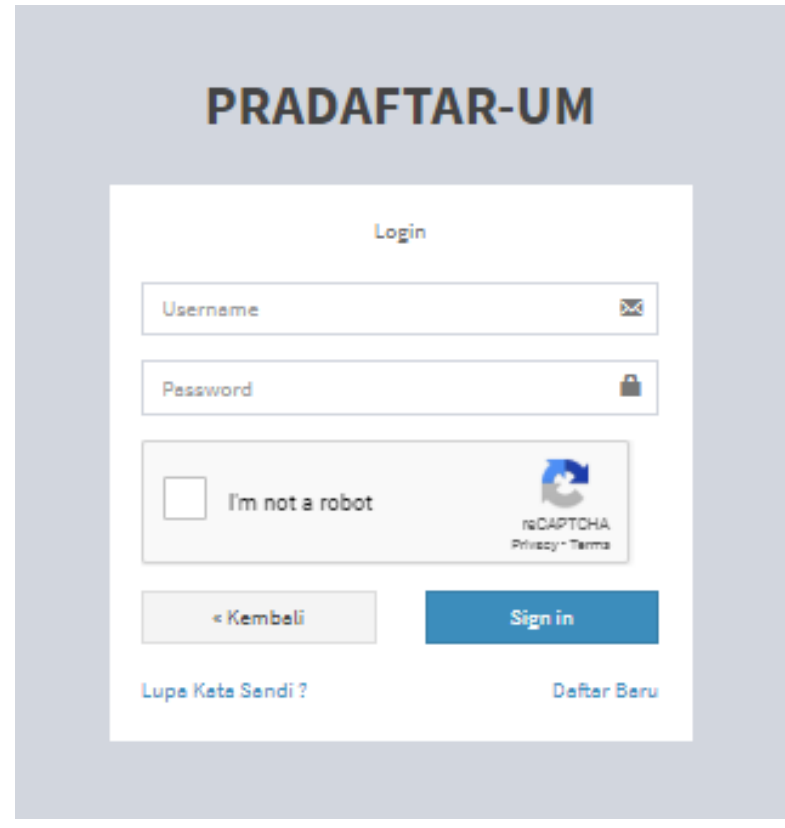

Gambar 6. Tampilan Halaman Login 


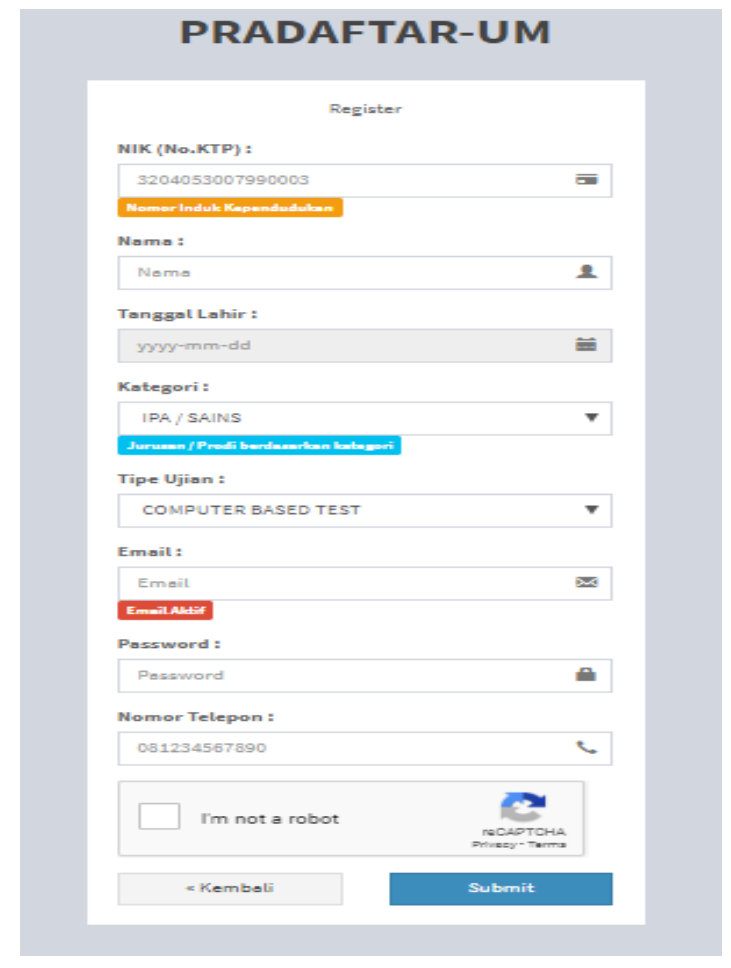

Gambar 7. Tampilan Halaman Pendaftaran

Penelitian ini menghasilkan produk aplikasi Penerimaan Mahasiswa Baru berbasis web. Rekomendasi dari penelitian ini terdapat yaitu pengembangan dengan menggunakan metode Prototyping Model merupakan cara untuk membuat system dengan cara tersusun dan memiliki tahapan-tahapan yang mesti dilewati dalam pembuatannya, system bisa saja terdapat kekurangan dan belum sempurna walau sudah sampai tahap akhir dan dinyatakan final. Oleh karena itu dibutuhkan evaluasi kembali.

\section{SIMPULAN}

Masing - Masing universitas mempunyai cara masing - masing dalam melaksanakan penerimaan mahasiswa baru, Sistem aplikasi yang dibuat masih harus dilengkapi dengan fitur-fitur tambahan untuk lebih mempermudah pendaftaran online seperti data-data yang berkaitan dengan alamat, nomor induk kependudukan, koreksi atas kekeliruan pengisian biodata.

\section{DAFTAR PUSTAKA}

Akbar, A., \& Noviani, N. (2019). Tantangan dan solusi dalam perkembangan teknologi pendidikan di Indonesia. PROSIDING SEMINAR NASIONAL PROGRAM PASCASARJANA UNIVERSITAS PGRI PALEMBANG.

Alviana, S., \& Kurniawan, B. (2019). Analisis Data Penerimaan Mahasiswa Baru Untuk Meningkatkan Potensi Pemasaran Universitas Menggunakan Business Intelligence (Studi Kasus Universitas XYZ). Infotronik: Jurnal Teknologi Informasi Dan Elektronika, 4(1), 10-15.

Anggito, A., \& Setiawan, J. (2018). Metodologi penelitian kualitatif. CV Jejak (Jejak Publisher).

Aziz, A. A., Nurfarida, R., Budiyanti, N., \& Zakiah, Q. Y. (2020). Model Analisis Kebijakan Pendidikan. Tapis: Jurnal Penelitian Ilmiah, 4(2), 192-201.

Islami, N. (2018). Manajemen Teknis Akreditasi Institusi Unggul Bagi Perguruan Tinggi Keagamaan Islam Negeri (PTKIN). Jurnal Tawadhu, 2(2), 588-610. 
Jannah, E. N., Bayturrohman, D. K., \& Kurniawan, E. (2017). Pengembangan Aplikasi Penerimaan Mahasiswa Baru Berbasis Android Dilengkapi dengan Fitur Push Notification. Jurnal Nasional Teknik Elektro Dan Teknologi Informasi (JNTETI), 6(4), 410-415.

Madjid, A. B. D. (2018). Analisis Kebijakan Pendidikan. Yogyakarta: Samudra Biru.

Moleong, L. J., \& Surjaman, T. (1991). Metodologi penelitian kualitatif. Penerbit PT Remaja Rosdakarya.

Mubarok, F., Harliana, H., \& Hadijah, I. (2015). Perbandingan Antara Metode RUP dan Prototype Dalam Aplikasi Penerimaan Siswa Baru Berbasis Web. Creative Information Technology Journal, 2(2), 114-127.

Muslihudin, M., \& Larasati, A. (2017). Perancangan sistem aplikasi penerimaan mahasiswa baru di stmik pringsewu menggunakan php dan mysql. Jurnal TAM (Technology Acceptance Model), 3, 32-39.

Muzhiat, A., \& Kartanegara, M. (2020). INTEGRASI ILMU DAN AGAMA; STUDI ATAS PARADIGMA INTEGRASI, KOMPARASI, DIFUSI MENUJU PERGURUAN TINGGI KEAGAMAAN ISLAM NEGERI (PTKIN) YANG UNGGUL. Al Qalam, 37(1), 69-88.

Panitia Pelaksana, S. d.-P. (2017). Prosedur Operasional Baku Ujian Masuk Perguruan Keagamaan Islam Negeri. Panitia SPAN-UM PTKIN.

Panitia Pelaksana Seleksi Penerimaan Mahasiswa Baru PTKIN. (2015). Prosedur Operasional Standar Seleksi Penerimaan Mahasaiswa Baru PTKIN. SPAN.

Panitia Penerimaan Mahasiswa Baru UIN SUSKA Riau. (2018). Undangan Mandiri. UIN SUSKA Riau. http://pmb.uin-suska.ac.id/site/menu/id/undanganmandiri

PTIPD UIN SGD. (2018). UIN SGD BANDUNG TERIMA KUNJUNGAN UIN JAKARTA TENTANG APLIKASI \& SERVER CBT. UIN SGD. https://ptipd.uinsgd.ac.id/?p=160

Suharto, B. (2021). Moderasi Beragama; Dari Indonesia Untuk Dunia. LKIS PELANGI AKSARA.

Sukmadinata, N. S. (2011). Metode Penelitian Pendidikan. Remaja Rosdakarya.

Suryadi, A. (2018). Sistem Rekomendasi Penerimaan Mahasiswa Baru Menggunakan Naive Bayes Classifier Di Institut Pendidikan Indonesia. Joutica, 3(2), 171-182.

Switri, E. (2019). Teknologi dan Media Pendidikan Dalam Pembelajaran. Ayra Luna.

Syahrum, S. (2012). Metode Penelitian Kuantitatif. Bandung: Citapustaka Media.

Tambunan, E. J. R., Hasibuan, A. F., Widyasari, A., Peristi, P., \& Bangun, B. (2020). RANCANG SISTEM INFORMASI MAHASISWA BARU. Journal of Student Development Information Technology (JoSDIT), 1(1), 5-9.

Tyas, Y. P. (2019). Aplikasi Berbasis Android Penerimaan Mahasiswa Baru pada Universitas PGRI Madiun. Prosiding Seminar Nasional Teknologi Informasi Dan Komunikasi (SENATIK), 2(1), 125-127.

Wahyudi, H. S., \& Sukmasari, M. P. (2018). Teknologi dan kehidupan masyarakat. Jurnal Analisa Sosiologi, 3(1). 